\title{
Aspectos habitacionais no Brasil: resumo histórico e estudo de caso da cidade de Uberlândia (MG)
}

\author{
Housing aspects in Brazil: \\ historical summary and case study of the city of \\ Uberlândia (MC)
}

\begin{abstract}
Raphaella karla portes Beserila * Pedro Luiz teixeira de camargo ** carmem Lúcia costa***
\end{abstract}

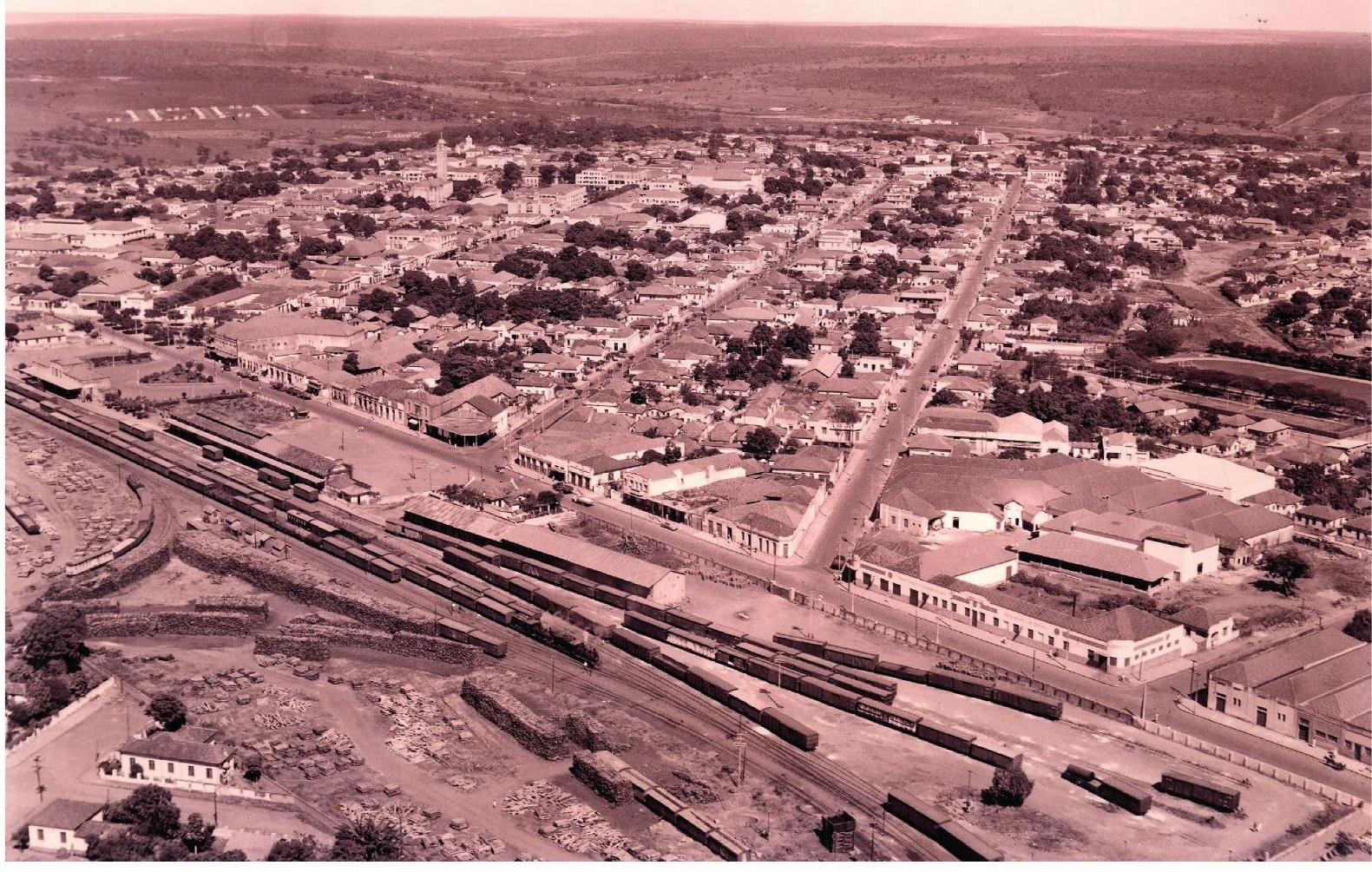

Vista aérea de Uberlândia em foto da década de 1940 


\section{RESUMO}

A falta de habitação para a classe trabalhadora é um problema histórico e estrutural que tem se perpetuado ao longo dos anos. Sua principal causa é a existência da propriedade privada, porém o Estado tenta contornar o problema de maneira errônea. Essa realidade não é diferente em Uberlândia (MG), onde desde a década de 1920 essa questão se tornou latente. $\mathrm{O}$ objetivo deste trabalho foi compreender as políticas habitacionais praticadas pelo Estado brasileiro, tendo como estudo de caso o município de Uberlândia. Como resultado foi possível apresentar um breve histórico das políticas públicas de habitação (PPHs) no Brasil desde os anos 1930, quando ocorreram as primeiras PPHs, até os tempos atuais. Para tal, nos utilizamos do levantamento bibliográfico, para fazer uma reconstituição histórica da questão no Brasil e em Uberlândia, e também da pesquisa documental, para entender os marcos legais pertinentes à questão. Diante disso, entendemos que é necessária uma transformação social e política profunda para que o Estado brasileiro garanta políticas habitacionais que atendam ao interesse da classe trabalhadora, sendo necessário, para isso, o rompimento com o Estado burguês, pois a essência do problema de moradia em nosso país perpassa a existência da propriedade privada.

Palavras-chave: Habitação. Social-democracia. Políticas públicas. Propriedade privada.

\section{ABSTRACT}

The lack of housing for the working class is a historical and structural problem, which has perpetuated itself over the years. Its main cause is the existence of private property, but the State tries to wrongly circumvent the problem. This reality is not different in Uberlândia (MG), where since the I920s this issue has become latent. The aim of this work was to understand the housing policies practiced by the Brazilian State, taking as a case study the city of Uberlândia. As a result, it was possible to present a brief history of public housing policies (PPHs) in Brazil since the 1930s, when the first PPHs occurred until the current times. We understand that a deep social and political transformation is necessary for Brazilian State to guarantee housing policies that meet the interests of working class, being necessary, for this, a break with the bourgeois State, because the essence of the housing problem in Brazil runs through the existence of private property.

Keywords: Housing. Social democracy. Public policies. Private property. 


\section{INTRODUCC̄̃O}

O espaço urbano é locus do estabelecimento das mais diversas relações sociais — sejam elas políticas, econômicas ou culturais —, ocorrendo tanto em macroescala, passando pelo Estado, como em microescala, configurando o lugar e o cotidiano. Essa diversidade de relações sociais torna a análise do espaço urbano complexa, e por isso partiremos do pressuposto de que todas as relações se fundamentam no modo de produção capitalista, uma vez que é essa a lógica vigente.

A constituição do urbano perpassa diferentes agentes, não se reduzindo aos que têm por objetivo facilitar a reprodução do capital, como os detentores dos meios de produção, os promotores imobiliários, os proprietários fundiários e o Estado, mas abrangendo também os grupos sociais historicamente excluídos; uma vez que o espaço urbano é finito, pode-se afirmar que todos, diariamente, disputam o mesmo espaço.

Ao se analisar a cidade, é importante levar em conta que ela é produto de uma construção humana ao longo da história, que se acumula com o passar das gerações, revelando diferentes possibilidades de uso e ocupação (CARLOS, 2004). A apropriação do espaço se dá justamente nas possibilidades de sua transformação, produzindo, nesse caso, além do urbano, o lugar que se desenvolve no plano da vida cotidiana.

A cidade, no capitalismo, se constitui em um "conjunto de diferentes usos da terra justapostos entre si" (CORRÊA, 2004, p. 7). As diversas utilizações estão inseridas e se organizam no espaço em função de mecanismos que têm como intuito a reprodução do capital (CORRÊA, 2004). A dinâmica no espaço urbano, que podemos entender como a organização espacial da cidade, dá-se de maneira concomitante, articulada e fragmentada, uma vez que cada parte desse todo se organiza estabelecendo relações entre si (CORRÊA, 2004).

Os diversos usos do espaço urbano propiciam uma disputa entre os agentes-detentores dos meios de produção e os grupos sociais excluídos, fazendo com que as transformações do solo urbano sejam processos complexos e dinâmicos, pois se realizam de maneira articulada e fragmentada, refletindo a lógica organizacional da sociedade de classes (CORRÊA, 1989). A disputa dos diversos agentes pelo solo urbano reflete a luta dessas classes, se organiza a partir da lógica do capital, que tem como princípio norteador a propriedade privada (MARX, I980).

A projeção espacial de uma sociedade dividida em classes pode ser compreendida pela questão habitacional (SOUZA, 20I6), e tem a sua concepção atrelada às raízes do capitalismo, pois, a partir do momento em que o trabalho ${ }^{1}$ se mercantiliza, "todos os outros aspectos da vida entram também nos circuitos do capital" (SOUZA, 2016, p. 68). A moradia, portanto, além de ser um elemento fundamental para a reprodução social, adentra os circuitos de troca, se tornando um item que é, "antes de mais nada, um objeto, produto, bem durável" (VALENÇA, 2003).

1 Para Marx (2013, p. 326), "o trabalho é, antes de tudo, um processo entre o homem e a natureza, processo este em que o homem, por sua própria ação, medeia, regula e controla seu metabolismo com a natureza". 
Sob o modo de produção capitalista, ocorre uma crise habitacional de ordem estrutural (SOARES, I988), uma vez que o capital entende a habitação como mercadoria, ou seja, para uma sociedade que se divide em classes, "o acesso à moradia se confunde com o acesso à propriedade” (LORENZETTI, 200I, p. 3). Assim, a aquisição de uma unidade habitacional limita-se a quem pode pagar pelo seu valor de uso.

Nessa perspectiva, a produção do espaço da cidade se dá de modo desigual e segrega as camadas populares, criando espaços suburbanos que, além de distantes dos centros comerciais e financeiros, apresentam condições insalubres de moradia.

A segregação socioespacial gira, mais uma vez, em torno dos interesses do modo de produção vigente. A existência das favelas e dos subúrbios urbanos só acontece por conta da especulação imobiliária, fazendo com que o especulador acumule um montante financeiro cada vez maior por meio da exploração dos vazios urbanos. A existência de mais unidades habitacionais em situação de vacância do que o chamado "déficit habitacional" continua a se perpetuar (MACIEL; BALTAZAR, 20II), pois é uma relação que favorece a reprodução especulativa. No caso do Brasil são cerca de 6 milhões de imóveis vazios e cerca de 6 milhões de famílias que não têm acesso a moradia, o que mostra como o problema não está relacionado a falta de unidades habitacionais mas a falta de acesso das famílias a habitação, que foi transformada pelo modo de produção capitalista em uma mercadoria (COELHO, 20I8).

A relação do aluguel é um bom exemplo de como o capital atua na questão habitacional, uma vez que o locador se apropria de parte do salário do locatário, configurando assim um processo de exploração indireta da mais-valia. Portanto, mesmo não ocorrendo uma relação de trabalho (MARX, 20I3), mas de comércio imobiliário, pode-se observar um processo no qual é possível constatar o acúmulo monetário graças à propriedade privada, sem relação direta com a exploração do trabalho (MARX, 20I3), mas ainda assim de exploração, evidenciando, dessa forma, como a propriedade privada tem relação direta com o chamado "déficit habitacional", o que nos faz refletir: será que existe mesmo essa falta de unidades habitacionais? Ou ela só existe pois o capital especulativo a mantém para sua própria sobrevivência e lucro?

As habitações têm um alto preço e valor, despertando assim o interesse de toda a população, principalmente por serem um bem necessário para a sobrevivência no modo de produção capitalista (MONTEIRO; VERAS, 20I7). O solo urbano, assim como as moradias, é tratado pelo capital como uma mercadoria, mediante a qual se busca o lucro, limitando-se o acesso a ela a quem pode pagar e excluindo a classe trabalhadora empobrecida (MONTEIRO; VERAS, 20I7). Essa conjuntura é uma das inúmeras formas da reprodução do capital, em função do lucro com os altos preços das habitações, o que cria um terreno fértil para a especulação imobiliária (MONTEIRO; VERAS, 20I7).

Para entender como esse processo ocorreu em Uberlândia (MG), inicialmente faremos uma compilação histórica com os principais marcos do surgimento e estabelecimento do espaço urbano; em um segundo momento buscaremos entender a questão habitacional da cidade, levantando os marcos legais e os programas de iniciativa local 
e nacional, com o objetivo de contextualizar o processo; no terceiro momento daremos ênfase aos programas recentes, a sua concepção ideológica e às novas legislações.

No intuito de cumprir esses objetivos, nos amparamos na pesquisa bibliográfica e documental para entender como foram constituídas as políticas de habitação ao longo da história, como o modelo de cidade se inseriu nesse processo e como isso afeta o acesso à habitação no Brasil e em Uberlândia, base do estudo de caso deste manuscrito.

\section{A QUUESTÃO HABITACIONAL EM UBERLÂNDIA (MG): UMA PROBLEMÁTICA HISTÓRICA}

O Sertão da Farinha Podre - conhecido hoje como Triângulo Mineiro — ganhou destaque na economia nacional em função da expansão da malha ferroviária, com a implantação da Estrada de Ferro Mogiana (I895), atual Ferrovia Centro-Atlântica; da construção da ponte Afonso Pena sobre o rio Paranaíba (I909), e da construção das rodovias pela Companhia Mineira de Autoviação (1912) (SOARES, 1988).

Ao desbravar o Sertão da Farinha Podre, em I8I8, o senhor João Pereira da Rocha, juntamente de sua família, acampou (e, posteriormente, tomou posse) nas proximidades do córrego São Pedro, marco do início da construção do que viria a ser Uberlândia. A constituição da cidade se iniciou em I856 com a implantação dos fundamentos do arraial, que um ano depois ganhou uma freguesia com o nome de Senhora do Carmo de São Sebastião da Barra de São Pedro do Uberabinha. Em I888, se tornou uma vila, conhecida por São Pedro do Uberabinha, e no ano de I892 foi emancipada, tornando-se cidade, mas só ganhou o nome de Uberlândia em outubro de 1929 (SOARES, I988).

Historicamente, é possível observar que no século XX diversas famílias migraram do campo para a cidade em busca de melhores condições de vida, acreditando na promessa de empregos que lhes oferecessem remunerações mais razoáveis, como mostra Soares (1988). Porém, a realidade encontrada era outra, faltavam serviços, os salários eram baixos e as políticas públicas com o intuito de atender a essa população eram praticamente inexistentes. Os locais onde a população de baixa renda conseguia se instalar apresentavam condições insalubres, precarizando ainda mais a vida do operariado.

Em Uberlândia não foi diferente. Com o número de indústrias em crescimento, a economia municipal já se destacava na década de I920 (SOARES, I988). Essas circunstâncias atraíam muitas pessoas para a cidade, porém esta já apresentava situações denominadas insalutíferas (SOARES, I988), isto é, não oferecia condições para o pleno desenvolvimento humano.

O jornal A Tribuna, de Uberlândia, noticiava em 1920 como a falta de moradias para a classe trabalhadora local já era um problema, ou seja, o déficit habitacional é uma antiga demanda que vem se arrastando ao longo dos anos (SOARES, I988), para ser exato, de décadas ou até séculos. As primeiras políticas públicas de habitação que abrangeram todo o território nacional foram implementadas somente no período 
da ditadura militar (1964-1985), com a criação do Banco Nacional da Habitação (BNH) logo após o golpe militar, em I964 (BOLAFFI, I982), ou seja, mais de 40 anos após as primeiras notícias na imprensa uberlandense.

Compreendendo a demanda histórica por moradia, e considerando a habitação como um espaço fundamental para a reprodução social de cada sujeito, pode-se afirmar que o Estado deveria atuar de forma a sanar essa questão, uma vez que é de sua responsabilidade o desenvolvimento de políticas que criem mecanismos para que a classe trabalhadora tenha acesso à moradia digna. Porém, a forma como as políticas são implementadas possibilita ao Estado usá-las como instrumento de controle social das massas operárias, como veremos a seguir.

Portanto, ao observar como os movimentos de luta pela moradia se dão por satisfeitos simplesmente por obter casas para os que não as têm, pode-se afirmar que esses mesmos movimentos não se organizam, efetivamente, por mudanças capazes de romper com a lógica do modo de produção capitalista, configurando-se, portanto, não como críticos da propriedade privada, mas sim como defensores do que se pode chamar de "capitalismo humanizado" ou simplesmente social-democracia².

O motivo ideológico para tamanha limitação de suas pautas de lutas se dá, justamente, pela limitação de seus líderes no entendimento epistemológico do que vem a ser "moradia" no modo de produção capitalista: uma mercadoria com valor de uso e de troca, capaz de servir tanto ao trabalhador como ao capital especulativo. Prova disso, inclusive, é o fato de existirem ferramentas econométricas capazes de precificá-la de acordo com o seu entorno, como o método dos preços hedônicos (CAMARGO, 20I8).

Não há dúvidas de que no Brasil exista um alto número de moradias em situação de vacância (como já explicado), porém o problema habitacional acaba sendo analisado e tratado numa perspectiva errônea, beneficiando o capital, pois o real problema não é (e nunca foi) a falta de casas, mas o fato de estas serem tratadas como mercadorias (tem acesso a elas quem pode pagar por seu valor). Em suma, seu déficit é da ordem do acesso e não da de unidades construídas (BOLAFFI, I982), ou seja, existem diversas propriedades que não estão cumprindo sua função social, desrespeitando assim a legislação específica acerca do tema, algo que, em essência, a maior parte dos movimentos sociais que lutam por moradia não aborda a fundo, configurando-se assim seu ímpeto de não rompimento com a lógica mercadológica do modo de produção vigente.

Ao se tratar a questão habitacional sob a perspectiva desse falso problema, o capital especulativo é beneficiado, pois este "cria" uma demanda de construção de novas moradias, fomentando assim o aumento da renda da terra, a especulação imobiliária e a exploração da mais-valia relativa por intermédio da ligação entre o especulador e a vítima da especulação.

Para compreender historicamente essa complexa simbiose entre esses sujeitos, é interessante observar como se deu a primeira iniciativa de implantar uma política de

2 A política social dos sociais-democratas consiste, geralmente, em mitigar os efeitos da distribuição dos recursos guiando-se pelo critério da eficiência. Essa política não visa transformar o sistema econômico, mas sim corrigir os efeitos de sua operação (PRZEWORSKI, 1988, p. 75). 
habitação de abrangência nacional, com a criação do Banco Nacional da Habitação (BNH) e do Sistema Federal de Habitação e Urbanismo pela lei federal no 4.380 , de 2I de agosto de 1964 .

Infelizmente, ambos não conseguiram atingir o seu propósito original, que era promover a construção e a distribuição de casas próprias, especialmente para as classes de menor renda (BOLAFFI, I982). Um dos motivos para que a efetivação dessa política não ocorresse foi que o BNH "terceirizava" as suas atribuições para a iniciativa privada, ficando incumbida esta de arrecadar e transferir os recursos financeiros necessários para a construção (BOLAFFI, I982).

Essa transferência de responsabilidade acabou por agravar o problema habitacional (em lugar de resolvê-lo, que era o seu objetivo inicial), uma vez que todas as deliberações ficavam à mercê dos interesses do mercado (BOLAFFI, 1982). Por não conseguir atingir os seus objetivos, em 1986 o BNH foi extinto e as suas funções foram transferidas para a Caixa Econômica Federal (vinculada ao Ministério da Fazenda). Já a área de habitação foi atribuída ao Ministério do Desenvolvimento Urbano e Meio Ambiente (BRASIL, 2004).

No principal período das ações do $\mathrm{BNH}$, curiosamente a ditadura militar, difundiu-se a ideia de que a casa própria representava um sonho de consumo, com segurança, estabilidade e condições favoráveis à reprodução social do núcleo familiar, eliminando o gasto com o aluguel que consumia parte significativa da renda das famílias mais pobres. Dessa forma, a questão habitacional era utilizada como instrumento de controle social, fazendo com que o trabalhador passasse de contestador da ordem vigente para seu aliado (AZEVEDO, I988).

Nesse contexto, podemos observar o processo de espoliação urbana, que é a privação das camadas populares do acesso a bens fundamentais para a sua reprodução social (KOWARICK, I979), como, por exemplo, a moradia. É importante ressaltar que a partir do momento em que o trabalhador adquire a casa própria, é gerado um processo de rebaixamento do custo de reprodução de sua força de trabalho, deprimindo ainda mais os seus já achatados salários (KOWARICK, I979).

A conjuntura econômica do Brasil na época áurea do BNH era o que ficou conhecido como "milagre econômico", no governo do general Emílio Garrastazu Médici (I969-1974), sendo que, a partir de 1974, o país entraria em uma profunda crise econômica, tornando a aquisição de moradia uma prioridade, principalmente para a classe trabalhadora, como forma de eliminar a despesa do aluguel (BOLAFFI, I982).

Os militares agiam de forma a fomentar o mercado imobiliário, pois era o capital especulativo que os financiava, portanto estavam 


\section{Uma das maiores críticas atribuídas à atuação do BNH é não ter conseguido atender justamente à parcela da população mais necessitada de moradia. Apesar de ser um dos seus objetivos oficiais, as práticas se davam em outro campo, no caso, o de financiar o empresariado responsável pela sustentação do golpe de 1964}

ligados de maneira direta ou indireta às empreiteiras. Um bom exemplo disso é que o BNH tinha inúmeras linhas de crédito para atender especialmente a esse público, impulsionando assim as atividades desses empresários que transacionavam de forma ampla com todas as classes sociais, em particular com as mais abastadas (CAMPOS, 20I8).

Nessa perspectiva, é possível observar que a atividade dos especuladores foi fortemente fomentada nesse período e deixou marcas e heranças que são visíveis até hoje nas cidades, em particular nas médias e grandes cidades, como a especulação imobiliária.

Entretanto, uma das maiores críticas atribuídas à atuação do BNH é não ter conseguido atender justamente à parcela da população mais necessitada de moradia. Apesar de ser um dos seus objetivos oficiais, as práticas se davam em outro campo, no caso, o de financiar o empresariado responsável pela sustentação do golpe de 1964, sendo relevante frisar que o objetivo de qualquer empresa sempre é obter lucros e aumentar o seu patrimônio, e não criar e apoiar mecanismos de acesso da classe trabalhadora à moradia — isso é um postulado óbvio no regime burguês (CAMPOS, 20I8).

A atuação do BNH em Uberlândia teve início no final da década de 1960, e deve ser compreendida sob diversos aspectos, pois ocorreu de distintas formas, uma vez que existiam diferentes tipos de financiamento e de agentes do mercado. As modalidades de financiamento dividiam-se em popular, econômica e média, representadas respectivamente pela Companhia de Habitação do Estado de Minas Gerais (Cohab-MG), Instituto de Orientação às Cooperativas Habitacionais (Inocoop-MG) e o Sistema Brasileiro de Poupança e Empréstimo (SBPE) (SOARES, I988).

Os conjuntos habitacionais construídos em Uberlândia, fruto da parceria entre a Cohab e o BNH, que foram direcionados para a classe trabalhadora, segundo Isidoro (2006, p. I8) 
possuíam características próprias e geralmente encontravam-se a grandes distâncias do centro da cidade. Em sua maioria apresentavam casas padronizadas e construídas com material de baixa qualidade. Na sua maioria, esses conjuntos foram localizados observando a distância permitida pelo $\mathrm{BNH}$, que era de 7 quilômetros do espaço geográfico central. A implantação desses conjuntos deixou imensos espaços vazios entre eles e a "cidade". Os conjuntos construídos pela Cohab serviram para os interesses políticos-econômicos com o objetivo de angariar votos e também serviram para promover a segregação urbana — espacial e social — na cidade de Uberlândia.

Pelos fatos mencionados por Isidoro (2006), podemos observar como a classe dominante atuava (e atua) no sentido de não resolver a questão habitacional, limitando-se a afastar dos centros urbanos as residências dos trabalhadores na tentativade esconder a pobreza e a miséria na qual vivia (e vive) o operariado empobrecido.

Na década de 1970, em função do crescimento acelerado da cidade de Uberlândia, houve uma expansão significativa na construção dos conjuntos habitacionais pelo BNH. O boom no número de moradias fez com que houvesse um aumento da renda da terra, e consequentemente a elevação do custo da edificação de novas moradias em localizações privilegiadas, outro exemplo de como a política do BNH não contemplava a classe trabalhadora (SOARES, I988).

O Conjunto Liberdade foi o único erguido em Uberlândia que tinha como objetivo alcançar a classe trabalhadora. A obra foi executada pela Cooperativa Cruzeiro do $\mathrm{Sul}^{3}$ em convênio com a Caixa Econômica Federal (CEF) de Minas Gerais e construiu 749 unidades habitacionais. Esse projeto fazia parte de um programa experimental que tinha como intuito deslocar a população de baixa renda, na perspectiva de erradicar as favelas, ou seja, é possível definir essa ação como uma política higienista que tinha como real propósito esconder a população pobre (SOARES, I988). Essa política, mais uma vez, fracassou, pois o proletariado local não possuía renda capaz de garantir a sua permanência no conjunto, levando à expulsão do público-alvo para os subúrbios urbanos (SOARES, I988).

A escolha dos locais onde eram construídos os conjuntos habitacionais em Uberlândia foi muito marcante, uma vez que a maioria se situava a mais de Io quilômetros de distância do centro da cidade, o que corrobora o propósito higienista aqui identificado e expressa a territorialização do capital no espaço urbano. Além disso, a cada novo conjunto, o arranjo espacial se modificava, reservando um vasto número de lotes para a especulação imobiliária (SOARES, I988).

O isolamento do trabalhador em bolsões de pobreza ${ }^{4}$, que tinham uma infraestrutura mínima - água, energia —, precarizava ainda mais a sua vida, principalmente com as distâncias a serem percorridas diariamente entre a moradia e o trabalho, coibindo o seu direito de acesso à cidade. Esse modelo de política habitacional excludente e rentista tem raízes na importação da política urbana higienista desenvolvida pelo Barão

3 Orientada pelo Inocoop-MG.

4 Locais com grande concentração da massa trabalhadora empobrecida. 
Haussmann, que expulsou o operariado francês do centro de Paris e o relegou para os subúrbios e periferias em I853 (LEFEBVRE, 200I), corroborando a exploração da mais-valia indireta por meio da locação de imóveis na Cidade Luz.

No Brasil, segundo Benchimol (I992), a reforma urbana iniciada em 1903 por Pereira Passos (tratado pelo autor como um Haussmann tropical) no Rio de Janeiro, na época capital da República, reproduz muitos dos aspectos da ideia realizada em Paris. A forma como essa reforma foi desencadeada implicou o aprofundamento das desigualdades e, consequentemente, a segregação socioespacial marcada pela divisão centro-periferia (GOMES, 2005).

A reestruturação urbana parisiense (e a carioca também) possui um aspecto estratégico-militar, já que, ao criar avenidas largas, objetivava, além de parecer moderna, inibir as manifestações populares (TOURINHO, 2007), neutralizando a atuação do movimento operário revolucionário francês (BENCHIMOL, I992), assim como a retirada da população pobre do centro - e isso vale tanto para o momento atual como para o contexto francês - era uma forma de conter a revolta das massas proletárias. De acordo com Harvey (20I2, p. 82), comentando a iniciativa do Barão de Haussmann:

Deliberadamente, ele planejou a remoção de grande parte da classe trabalhadora e outros elementos rebeldes do centro da cidade, onde constituíam uma ameaça à ordem pública e ao poder político. Ele criou uma forma urbana onde se acreditava — incorretamente, como se evidenciou em I87I — que um nível suficiente de vigilância e controle militar poderia assegurar que o movimento revolucionário seria facilmente submetido.

A relação com a cidade era muito importante para os operários franceses, mas foi interrompida de maneira abrupta pela reforma urbana, que inclusive os expropriou de suas moradias. Não por acaso, reestabelecer o convívio com o centro da capital francesa tornou-se um dos objetivos da Comuna de Paris (LEFEBVRE, 200I). Marx, na obra O I8 brumário de Luis Bonaparte (20II), ao avaliar ambas as ações, deixa claro como projetos político-sociais burgueses em confronto podem favorecer a implementação de ideias conservadoras, como foi, em essência, a proposta do Barão de Haussmann.

Em ambos os casos (Paris e Rio de Janeiro) podemos observar que as classes dominantes atuaram ao lado do Estado com o discurso de "modernizar" as cidades, quando na verdade o objetivo era expulsar os trabalhadores do centro. Após a "limpeza" das regiões principais, o capital especulativo ganhou força em sua ação, tendo como consequência o aumento da renda da terra e a elevação do preço do solo urbano, por meio de obras de infraestrutura financiadas pelo Estado (CARVALHO, 20I3).

Ao ser expulso dos centros urbanos, o operariado continua sendo alvo da exploração da mais-valia indireta em consequência da relação locador-inquilino, ou seja, até para se ter acesso temporário (e extremamente limitado) ao imóvel, é necessário dispor de renda suficiente. Aliás, as condições de moradia da classe trabalhadora pioraram enormemente com a sua expulsão para os espaços suburbanos. 
Essa situação mostra como os detentores dos meios de produção (e do capital) fazem disso um jogo de cartas marcadas, utilizando o aparelho do Estado em prol de seus interesses particulares, não tendo compromisso em fomentar e implantar políticas públicas eficientes para melhorar a vida do povo mais humilde, mesmo diante das contradições que esse comportamento suscita, como a eclosão de revoltas populares.

Essas circunstâncias também ocorreram no período histórico no qual o BNH atuou (I964-I986); mesmo apresentando políticas de moradia insuficientes, essa instituição deixou heranças significativas, principalmente na forma como são executadas as políticas habitacionais até hoje. Exemplo disso é a reprodução de modelos de condomínios horizontais nas periferias urbanas, isolando, precarizando e privando a classe trabalhadora do direito à cidade ${ }^{5}$, em uma lógica perversa que, na prática, criou (e segue criando) bolsões de pobreza. A contradição das políticas habitacionais se dá pelo fato de não se achar uma "solução" para a questão habitacional da classe trabalhadora, mas criar novos problemas como o de mobilidade urbana e o de aumento da renda da terra. No caso da cidade de Uberlândia, essa demanda se apresenta desde meados de I924.

$\mathrm{Na}$ segunda metade da década de I920, quando a cidade (na época conhecida como Uberabinha) já se destacava na economia nacional - tendo como principal atividade a produção das charqueadas, que abastecia o Rio de Janeiro, São Paulo, o Nordeste e outras regiões de Minas Gerais (SOARES, 1988) —, a falta de mecanismos legais para a resolução desse grave problema social se mostrava cada vez mais presente.

Os operários das principais indústrias locais moravam próximo ao frigorífico Ômega, e viviam em condições insalubres. Cabe salientar que esses trabalhadores eram contratados apenas na época de alta na produção, que ia de janeiro a julho, e passavam o restante do ano desempregados (SOARES, I988), aumentando assim o exército de reserva local, o que barateava, ainda mais, o custo do empregado nas relações de trabalho no município. Isso não se dava por acaso, pois, como Marx (1980) mostra, diminuir o custo da força de trabalho pela criação de empregos em quantidade muito menor que a oferta de mão de obra não é uma estratégia do século XX, já era comum em toda a Europa desde o século XIX.

Na segunda metade da década de 1920, cabe destacar que a indústria foi se expandindo com a acomodação de empresas ligadas ao setor agrícola, que, com o intuito de facilitar o escoamento da produção pela estação ferroviária municipal, se instalaram nas saídas da cidade. A Cia Industrial do Triângulo Mineiro foi o empreendimento que mais cresceu economicamente na época, ofertando emprego e até mesmo um conjunto habitacional, as chamadas vilas operárias, para os seus funcionários (SOARES, I988).

5 O Estatuto das Cidades é um importante instrumento que oferece mecanismos de acesso, mesmo com as limitações da social-democracia, da classe trabalhadora à cidade. Entendemos que a classe trabalhadora só terá o pleno acesso à cidade em outro modelo de sociedade, em que o modo de produção vigente não seja o capitalismo. Nessa perspectiva, faz-se necessária uma transformação social e política profunda, em decorrência da qual a prioridade passe a ser o ser humano, e não mais a reprodução do capital. 
Com o crescimento do setor industrial uberlandense, a busca por melhores empregos atraiu, já nessa época, muitas pessoas para a cidade (como já descrito). Ao se depararem com outra realidade, a da dificuldade em encontrar trabalho, por conta do grande contingente de exército de reserva (MARX, I980), as famílias acabavam se instalando em locais precários, uma vez que não possuíam renda nem mesmo para o pagamento de aluguéis. Assim, nessa época (segunda metade da década de 1920), Uberlândia já apresentava um significativo déficit de moradia, que inclusive foi tema de matérias do jornal A Tribuna, que citava o fato de a classe operária não ter habitação própria (SOARES, I988).

Ainda nessa década, além da Cia Industrial do Triângulo Mineiro, também a Companhia Ferroviária Centro-Atlântica e as charqueadas construíram casas para serem alugadas a seus trabalhadores. A habitação, nesse caso, não era uma tentativa de resolver o problema habitacional dos operários, mas de controlar a força de trabalho, sendo mais um instrumento de sua expropriação. Essas moradias eram utilizadas como uma maneira eficaz de coibir a organização dos trabalhadores na reivindicação dos seus direitos, pois, em caso de enfrentamento contra os patrões por mais direitos trabalhistas, o operário poderia perder, além do vínculo empregatício, também o seu local de moradia. Na prática, isso era uma estratégia para fazer com que os proletários aceitassem todas as condições que lhes eram impostas (diga-se de passagem, muito precárias), além, evidentemente, dos baixos salários (SOARES, 1988).

A expansão da malha urbana em função da atividade industrial fez com que um novo agente da produção do espaço entrasse em ação, os agentes imobiliários, que passaram a atuar principalmente em torno da especulação financeira. Essa situação fez com que o déficit habitacional fosse se agravando ao longo do tempo.

Uma vez que o capital entende a habitação como mercadoria, ela passa a ter valor de troca. Para Marx (I980, p. 2IO-2II):

O produto, de propriedade privada, é um valor de uso, fios, calçados etc. Mas, embora calçados sejam úteis à marcha da sociedade e nosso capitalista seja um decidido progressista, não fabrica sapatos por paixão aos sapatos. $\mathrm{Na}$ produção de mercadorias, nosso capitalista não é movido por puro amor aos valores. Produz valores de uso apenas por serem e enquanto forem substrato material, detentores de valor de troca.

Ou seja, uma sociedade que se divide em classes, na qual a classe hegemônica atua para limitar o acesso a um determinado bem de consumo a quem pode pagar por ele, faz com que as moradias passem a ser fatores de choque social, sendo necessárias, assim, políticas públicas de habitação não só para a classe trabalhadora viver, mas para conter possíveis revoltas populares por conta dessa situação.

Portanto, a criação do BNH e da Cohab, na década de I960, no fundo, servia para acalmar os ânimos do operariado liderado, de maneira geral, por sindicatos que sofriam influência trabalhista ou comunista, ideias em voga entre os operários na época 
e contrárias ao regime ditatorial então vigente no país. A iniciativa estatal era similar às reformas de Von Bismarck na Alemanha, com a criação do seguro social para garantir a adesão de parte do proletariado ao seu governo de cunho autoritário (BIHR, 20Io).

É importante ressaltar que o Banco Nacional da Habitação foi extinto em I986, com seus funcionários sendo absorvidos pela recém-criada Caixa Econômica Federal (CEF). A partir desse momento, a política habitacional passou a apresentar um vácuo, uma vez que suas funções foram repartidas entre vários órgãos do Governo Federal (MEDEIROS, 20IO).

Após a extinção do $\mathrm{BNH}$, o município de Uberlândia não desenvolveu mais políticas eficientes para atender à demanda habitacional, ficando refém, basicamente, das iniciativas federais até a metade dos anos 2000, fazendo com que os movimentos sociais de luta pela moradia tivessem uma atuação mais fervorosa e, consequentemente, que o número de ocupações crescesse nesse período (MACÊDO, 20I4).

No contexto nacional, a política de habitação do governo Sarney (1985-1990) é marcada por uma grande confusão institucional em função da frequente reformulação dos órgãos responsáveis. Em 1985, o Ministério do Desenvolvimento Urbano e Meio Ambiente transformou-se em Ministério da Habitação, Desenvolvimento Urbano e Meio Ambiente e, em seguida, em Ministério da Habitação e Bem-Estar Social, sendo extinto em 1989 e a habitação ficando a cargo do Ministério do Interior. Essas circunstâncias, consequentemente, fortaleceram programas alternativos como o Programa Habitacional de Mutirões Comunitários, que tinham como objetivo alcançar famílias com até três salários mínimos, e como meta construir 550 mil unidades habitacionais (NOAL \& JANCZURA, 2OII). Porém, essa política foi um verdadeiro fracasso, não atingindo nem mesmo um terço das metas estabelecidas (BOTEGA, 2007).

Em I988, foi aprovada a nova Constituição Federal, conhecida como Constituição Cidadã, que passou a tratar de forma inédita as questões urbanas:

Art. I82. A política de desenvolvimento urbano, executada pelo poder público municipal, conforme diretrizes gerais fixadas em lei, tem por objetivo ordenar o pleno desenvolvimento das funções sociais da cidade e garantir o bem-estar de seus habitantes.

$[\ldots]$

$\$ 2^{\circ}$ ) A propriedade urbana cumpre sua função social quando atende às exigências fundamentais de ordenação da cidade expressas no plano diretor.

[...]

Art. I83. Aquele que possuir como sua área urbana de até 250 metros quadrados, por cinco anos, ininterruptamente e sem oposição, utilizando-a para sua moradia ou de sua família, adquirir-lhe-á o domínio, desde que não seja proprietário de outro imóvel urbano ou rural.

$\left.\$ \mathrm{I}^{\circ}\right) \mathrm{O}$ título de domínio e a concessão de uso serão conferidos ao homem ou à mulher, ou a ambos, independentemente do estado civil. 
Modelo de política habitacional excludente e rentista tem raízes na importação da política urbana higienista desenvolvida pelo Barão Haussmann, que expulsou o operariado francês do centro de Paris e o relegou para os subúrbios e periferias em 1853

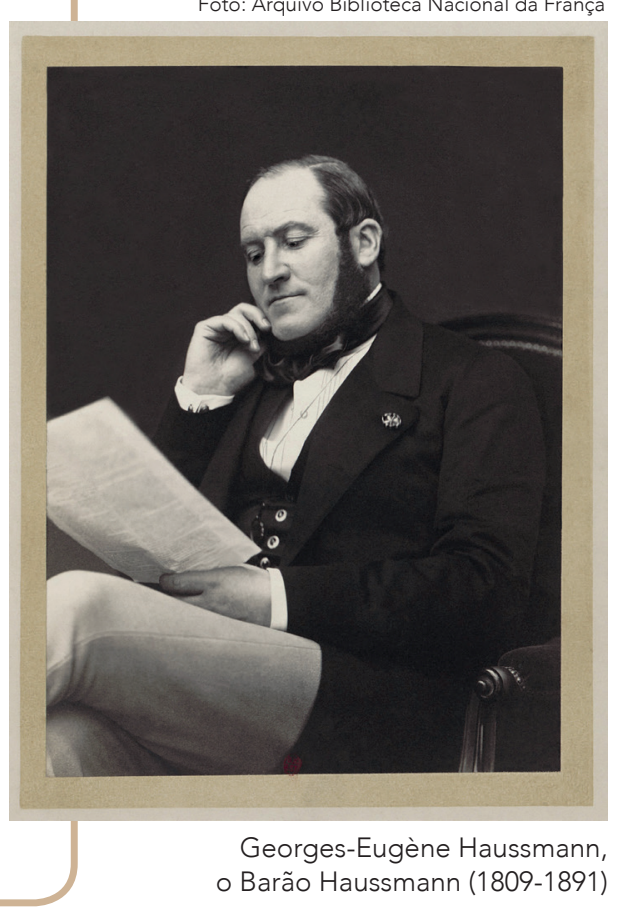

$\$ 2^{\circ}$ ) Esse direito não será reconhecido ao mesmo possuidor mais de uma vez. $\$ 3^{\circ}$ ) Os imóveis públicos não serão adquiridos por usucapião (BRASIL, I988, destaques nossos).

Os avanços da Constituição Federal de 1988 são incomparáveis e trazem instrumentos inovadores como a autonomia dos municípios em relação à política urbana. Porém, incluem-se alguns entraves, principalmente em relação à função social da propriedade privada, cabendo ao poder público local observar se tal política está sendo cumprida ou não, sem que se detalhe qual instrumento deve ser utilizado nessa avaliação (BRITO, 20I7).

Cronologicamente, o primeiro presidente eleito de forma direta após a ditadura militar foi Fernando Collor de Mello (1990-1992). No seu governo, a pasta de habitação passou do extinto Ministério do Interior para o Ministério da Ação Social, e teve como principal ação o Plano de Ação Imediata para a Habitação (Paih). Esse programa foi lançado em 1990, tendo como meta construir, em caráter de urgência, 245 mil unidades habitacionais em I8o dias, por intermédio de parcerias público-privadas (PPPs) com empreiteiras. O seu objetivo era reestruturar o setor imobiliário e da construção civil (RIBEIRO, 2007), deixando claro que o propósito não era em nenhum momento criar mecanismos de acesso à moradia para a classe trabalhadora empobrecida.

O Paih se dividia em três linhas de atuação: o Programa de Moradias Populares (unidades acabadas); o Programa de Lotes Urbanizados — com ou sem cesta básica de 
materiais - , promovido pelas Cohabs e as cooperativas e entidades de previdência, e o Programa de Ação Municipal para Habitação Popular (unidades acabadas e lotes urbanizados), que era de inteira responsabilidade dos municípios.

O programa tinha como objetivo, também, testar novas matérias-primas e técnicas na construção civil, que passariam pela aprovação da equipe técnica da CEF, que atuava de forma secundária na implementação das linhas dos programas pelos agentes promotores (MOURA; SOARES, 2009).

A principal característica da linha de atuação do governo Collor foi a criação de mecanismos que facilitassem a prática do clientelismo, direcionando a aplicação dos recursos, inclusive no que se refere à habitação (RIBEIRO, 2007). O Paih foi considerado uma política segregacionista e contraditória, pois privilegiava os interesses privados em detrimento dos interesses da classe trabalhadora, que, além de ter de cumprir uma série de exigências legais para com a CEF, recebia um imóvel de $23 \mathrm{~m}^{2} \mathrm{em}$ péssimas condições de infraestrutura urbana e acabamento, sem saneamento básico e longe do centro da cidade, criando mais uma vez verdadeiros bolsões de pobreza (FERREIRA, 2009; MOURA; SOARES, 2009).

Essa política foi um verdadeiro fracasso, pois o prazo para a entrega das moradias foi aumentado de 6 para I8 meses, enquanto a meta de unidades habitacionais a construir diminuiu de 245 mil para 2IO mil. Portanto, o objetivo inicial também não foi alcançado, sendo que um dos empecilhos para tal foi a falta de recursos (FERREIRA, 2009), além, por óbvio, de se evidenciar a incapacidade das políticas habitacionais em atender às famílias com renda de até três salários mínimos - uma herança do extinto $\mathrm{BNH}$.

Em 1992, com o impeachment de Collor, as obras do Paih foram suspensas em função de inúmeras denúncias de irregularidades em relação a sua execução. Ao assumir a presidência, Itamar Franco (I992-I994) suspendeu definitivamente o programa em função dos altos custos financeiros, paralisando a construção de 12 mil casas em todo o país.

Ainda sob a batuta de Itamar Franco, reestruturou-se a gestão pública e foram criadas novas políticas habitacionais, sob comando do então Ministério do Bem-Estar Social, passando a se exigir a participação dos conselhos comunitários, a contrapartida dos governos locais e o financiamento por parte da União, sendo fundamental frisar que essas mudanças aumentaram de forma significativa o controle social e a transparência em relação a essas políticas (ARIMATEIA, 2006).

O mesmo governo criou duas frentes de atuação no que diz respeito à habitação popular, sendo que uma delas foi lançada em I993, o Programa Habitar Brasil, com o objetivo de enfrentar o problema habitacional das famílias de baixa renda nas médias e grandes cidades, entendidas na época como as que possuíam mais de 50 mil habitantes.

Os principais critérios para participação no programa eram dispor de renda inferior a três salários mínimos, não ter participado de outro programa habitacional, 


\section{Em 2002, com a eleição}

de Luiz Inácio Lula da

Silva (PT), havia muitas

expectativas com

relação à temática que

envolvia a produção de

moradias populares no

novo governo

possuir apenas um imóvel e estar vivendo em locais que não apresentassem condições salubres de habitação (ARIMATEIA, 2006). Com objetivos semelhantes, porém voltados para as pequenas cidades, foi lançado também em I993 o Programa Morar Município (segunda frente de atuação) (FERREIRA, 2009).

Apesar dos avanços dessas políticas, como o reconhecimento da problemática habitacional e a criação de mecanismos de controle social e transparência, existem muitas divergências na literatura sobre o alcance dos objetivos propostos, principalmente porque houve dificuldade em abarcar os recursos financeiros advindos tanto de verbas orçamentárias como do Imposto Provisório sobre Movimentação Financeira (IPMF) (MOURA; SOARES, 2009).

Outra mudança fundamental nesse período foi o estabelecimento de um novo conceito de déficit habitacional encomendado pelo governo. A Fundação João Pinheiro (FJP) passou a considerar não só o número de unidades habitacionais oferecidas pelo poder público, mas também outras variáveis, como água tratada, esgoto, coleta de lixo, iluminação pública, adensamento e posse precária. Esse conceito é o mesmo usado atualmente, e marcou um novo momento nas políticas habitacionais no Brasil (SOUZA, 2009).

O início do governo de Fernando Henrique Cardoso (FHC, 1995-2003) teve como principal característica, no que tange à política habitacional, a descentralização dos recursos e maiores exigências legais para a realização dos empréstimos federais que tivessem como objetivo a aquisição de moradias (ARRETCHE, 2002). Nesse sentido, ocorreu uma reforma administrativa mais robusta, que teve como consequência uma reestruturação institucional, extinguindo o Ministério do Bem-Estar Social e criando a Secretaria de Política Urbana (Sepurb), alocada no Ministério do Planejamento e Orçamento, que passou a ser o responsável pela estruturação da Política Nacional de Habitação.

Nesse período, houve ainda a elaboração e diversificação dos programas habitacionais: Programa Habitar Brasil, Pró-Moradia, Carta de Crédito Individual Associativo e Apoio à Produção; entretanto, esses programas não dialogavam entre si, tendo 
como consequência uma política dispersa em diversas iniciativas. É importante salientar que nenhum desses programas atingiu êxito (MOREIRA; LEME, 2OII).

Em 1999, foi lançado o Programa de Arrendamento Residencial (PAR), que se diferenciava dos demais programas pela forma como se dava o financiamento e a alienação fiduciária pela CEF, sendo que a fonte dos recursos destinados ao programa advinha do FGTS e de recursos considerados não onerosos para a União. O programa tinha como público-alvo famílias com renda de até seis salários mínimos, e sua principal ação foi a de reativar a construção dos conjuntos habitacionais na malha urbana já dotada de infraestrutura (BONATES, 2008).

O grande avanço da era FHC ocorreu em 200I, com a aprovação pelo Congresso Nacional e a sanção presidencial do Estatuto das Cidades, projeto que tramitava havia I3 anos e regulamentava a Constituição de 1988 criando possibilidades para que a função social da propriedade privada fosse cumprida, além de ser um importante instrumento para o equacionamento da questão habitacional no Brasil (BONDUKI, 2008). É necessário salientar que o governo FHC não se empenhou para que o projeto de lei do Estatuto das Cidades fosse aprovado, o que contou com a persistência dos movimentos sociais de luta pela moradia e pela reforma urbana (MARICATO, 1998).

Em 2002, com a eleição de Luiz Inácio Lula da Silva (PT), havia muitas expectativas com relação à temática que envolvia a produção de moradias populares no novo governo escolhido pelo povo, uma vez que sua orientação ideológica parecia oposta à visão neoliberal de FHC.

O plano de governo do petista continha uma parte dedicada exclusivamente à moradia, na qual propunha o combate ao déficit habitacional com base no estímulo à construção de novas moradias - o que também aqueceria a indústria da construção civil —, orientando-se pela Constituição de I988 e suas regulamentações e buscando, assim, que a propriedade privada cumprisse enfim a sua função social (COLIGAÇÃO LULA PRESIDENTE, 2002).

\section{REFORMA OU REVOLUÇ̃̃O? A HABITAÇÃO NA ERA DOS GOVERNOS PETISTAS: DESDOBRAMEN- TOS NACIONAIS E LOCAIS}

A maneira como a social-democracia tomou forma no Brasil no pós-1988 é muito curiosa (DEO, 20II). Mesmo cercadas de bastante expectativa por parte do eleitorado que levou o primeiro operário à Presidência da República, as ações petistas, em relação a essa temática das políticas habitacionais, foram similares àquelas da ditadura militar.

O motivo, obviamente, era o mesmo: mediar a "crise" habitacional e garantir bônus político. Portanto, a lógica dos governos liderados pelo Partido dos Trabalhadores (PT), bem como a de qualquer outro de orientação social-democrata, é muito similar, pois é reformista, melhorando a vida do povo sem romper com a lógica do modo de produção capitalista (DEO, 20II). Para isso, foi criado o Ministério das Cidades. 
A constituição desse ministério é fruto de uma ampla luta política acumulada ao longo dos anos pelos movimentos sociais progressistas (também de orientação social-democrata em sua maioria, como visto no início do artigo), e parecia se confirmar como um marco que traria avanços (institucionais) para as cidades brasileiras (MARICATO, 20II).

Entre esses avanços, podemos destacar o fato de o ministério possuir em sua estrutura interna uma secretaria específica para tratar somente da habitação, algo não implantado antes pelo ex-presidente neoliberal ${ }^{6}$ FHC, de matriz ideológica oposta à do ex-presidente petista. Cabe destacar ainda que a criação da Secretaria de Habitação surgiu durante a transição entre os governos FHC e Lula "com base nos principais problemas sociais que afetavam as populações urbanas" (MARICATO, 20II, p. 26).

Os diversos estudos realizados pelo "novo" Ministério das Cidades, apoiados nos dados do Censo Demográfico de 2000 e da Pesquisa de Informações Municipais de 20oI do Instituto Brasileiro de Geografia e Estatística (IBGE), mostraram que o déficit habitacional na área urbana das cidades brasileiras correspondia, naquele momento, a cerca de 5,5 milhões de moradias (BRASIL, 2004).

Com base nesse diagnóstico, foi proposta a Política Nacional de Habitação (PNH), em sincronia com a Constituição Federal, que trata a moradia como direito fundamental de cada cidadão no seu artigo $6^{\circ}$ :

São direitos sociais a educação, a saúde, a alimentação, o trabalho, a moradia, o transporte, o lazer, a segurança, a previdência social, a proteção à maternidade e à infância, a assistência aos desamparados, na forma desta Constituição (BRASIL, I988).

Assim o Estatuto das Cidades estabelece a função social da propriedade, no art. I82, $\$ 2^{\circ}$ : "A propriedade urbana cumpre sua função social quando atende às exigências fundamentais de ordenação da cidade expressas no plano diretor." Dentre os objetivos da PNH, cabe destacar a provisão da habitação, uma vez que o oferecimento de moradia digna para a população de baixa renda era o principal intuito dessa política (BRASIL, 2004).

Em 2005, em continuidade com a visão progressista de que a moradia é um direito fundamental do cidadão, e como forma de dar prosseguimento à $\mathrm{PNH}$, criou-se o Sistema Nacional da Habitação de Interesse Social (SNHIS) e instituiu-se o Fundo Nacional da Habitação de Interesse Social (FNHIS), através da lei no II.I24, de I6 de junho de 2005 .

A principal meta do SNHIS era criar mecanismos para que as populações de baixa renda tivessem acesso à moradia digna por meio de programas de investimentos

6 Segundo Moraes (2001), o termo neoliberalismo carrega ao menos três significados: 1) uma corrente de pensamento e uma ideologia, isto é, uma forma de ver e julgar o mundo social; 2) um movimento intelectual organizado que realiza reuniões, conferências e congressos, edita publicações, cria think tanks; 3) um conjunto de políticas adotadas pelos governos neoconservadores sobretudo a partir da segunda metade dos anos 1970 e propagadas pelo mundo por organizações multilaterais criadas pelo acordo de Bretton Woods (1945). 
e subsídios, assim como ocorria com as Cohabs, sendo que, neste caso, as unidades habitacionais direcionadas à população trabalhadora de renda baixa - compreendida entre I e 3 salários mínimos - acabavam por ser vendidas a quem tinha renda maior que o teto determinado, ou seja, de modo similar ao praticado na ditadura, também não alcançavam o público-alvo.

Um dos princípios orientadores do SNHIS era garantir que a moradia passasse a ser tratada como um direito:

Art. $20^{\circ}$. Fica instituído o Sistema Nacional de Habitação de Interesse Social SNHIS, com o objetivo de:

I — viabilizar para a população de menor renda o acesso à terra urbanizada e à habitação digna e sustentável;

II - implementar políticas e programas de investimentos e subsídios, promovendo e viabilizando o acesso à habitação voltada à população de menor renda; e

III — articular, compatibilizar, acompanhar e apoiar a atuação das instituições e órgãos que desempenham funções no setor da habitação (BRASIL, 2005, destaques nossos).

Esses mecanismos podem ser entendidos por meio dos marcos legais que foram firmados para dar sustentação às possíveis políticas e/ou programas habitacionais, como foi colocado em prática a partir de 2009.

A moradia já tinha sido incluída na Constituição Federal como direito fundamental cinco anos antes, no artigo $6^{\circ}$ da Constituição de 1988 , pela emenda constitucional $n^{\circ} 26$, de I4 de fevereiro de 2000, como um mecanismo potencializador de inclusão social, visto que o não acesso excluía milhares de brasileiros de viver em circunstâncias salubres, ou seja, de obter plenas condições para o seu desenvolvimento humano e social. Mesmo com esse avanço, é preciso observar que a social-democracia procura "resolver" a questão habitacional de maneira equivocada, pois não ataca o problema em sua essência, que é a existência da propriedade privada, buscando assim formas de "reformar" ou "revisar" o capitalismo.

Talvez o primeiro ideólogo dessa ideia tenha sido Bernstein, um dos líderes da II Internacional e defensor dos avanços dos direitos dos trabalhadores através de reformas sociais e da democratização política do Estado. Obviamente, essas ideias (similares às implantadas por Lula e Dilma) não levam em conta o próprio movimento histórico do capitalismo, contribuindo assim para a manutenção da sua dominação. Para Luxemburgo (2003, p. 69), "a tese revisionista é apenas uma adaptação ao capitalismo e representa o enterro do socialismo, baseado numa concepção vulgar da economia”. Tal observação desnuda a concepção petista de apenas reformar, e não de subverter a lógica da exploração de classes.

Esses processos se reproduzem, no âmbito municipal, e em consonância com a política nacional então em voga, na Prefeitura Municipal de Uberlândia (PMU). O 
governo da cidade criou a lei $\mathrm{n}^{\circ}$ 9.080, de 25 de outubro de 2005, que instituiu o Plano Municipal de Habitação (PMH) Tchau Aluguel. Esse plano tinha como objetivo facilitar o acesso do povo a melhores condições habitacionais (UBERLÂNDIA, 2005), algo que, como será possível observar, não aconteceu.

O Tchau Aluguel tinha como público-alvo as famílias com renda de até três salários mínimos ${ }^{7}$, principalmente residentes em Uberlândia durante pelo menos três anos, e que não tivessem imóveis registrados em seu nome - condição a se comprovar pela apresentação de certidão negativa de propriedade de imóveis (UBERLÂNDIA, 2005).

A execução dessa política se deu, em especial, através de convênios entre entidades públicas, como a CEF, privadas ou na forma de mutirões para autoconstruções (UBERLÂNDIA, 2005). As formas de financiamento e execução foram muito semelhantes às do BNH, que operava na ditadura militar. Em ambos os casos, havia como real objetivo a reprodução do modo capitalista como consequência da atuação em favor dos especuladores e empresários da construção civil e pela relação estabelecida na contratação das empreiteiras, ainda que por meio das licitações conforme a Constituição de 1988 - no caso do BNH, era favorecida a empreiteira que tivesse relação com os militares. Algo também bastante semelhante à atuação do $\mathrm{BNH}$, que favoreceu a elite nacional, aliás a mesma que havia financiado o golpe militar de I964 (CAMPOS, 20I8), assim como as construtoras financiaram a campanha eleitoral do então prefeito, Odelmo Leão Carneiro, que tinha como vice o senhor Aristides Antônio de Freitas Borges, curiosamente o dono da maior imobiliária da cidade.

Estabelecendo parcerias com o mercado especulativo local, o PMH Tchau Aluguel teve um início extremamente tímido, com a edificação e entrega de I83 casas em 2008 (tabela I).

\section{Tabela I - Moradias construídas e entregues pelo Programa Tchau Aluguel - Uberlândia (MG), 2008}

\begin{tabular}{llll}
\hline Programa & Bairro/local & Tipologia & Unidades \\
\hline Tchau Aluguel & Campo Alegre & Casas & 158 \\
Tchau Aluguel & Distrito de Tapuirama & Casas & $\mathbf{2 5}$ \\
\hline Total & & & $\mathbf{1 8 3}$ \\
\hline
\end{tabular}

Fonte: Banco de Dados Integrado da Prefeitura Municipal de Uberlândia (UBERLÂNDIA, 2009).

A lei que institui o PMH foi sancionada em 25 de outubro de 2005, portanto três anos antes da entrega das primeiras unidades. É importante ressaltar que o BDI da PMU não informa se o financiamento era de ordem local e/ou federal, deixando um vazio acerca dessa questão e demonstrando falta de transparência por parte da gestão pública da época.

7 Na época que a lei foi sancionada, no ano de 2005, o salário mínimo era de $\mathrm{R} \$ 300$. 
$\mathrm{O}$ auge do $\mathrm{PMH}$ se deu no ano de 20Io, quando, na prática, em um único conjunto habitacional foram entregues I.36I moradias, sendo I.I36 unidades habitacionais no bairro Jardim Célia (tabela 2). Ainda em 20I0, foram entregues mais 225 unidades, com destaque para os I76 apartamentos construídos no Bairro São Jorge ${ }^{8}$.

Tabela 2 - Moradias construídas e entregues pelo Programa Tchau Aluguel - Uberlândia (MG), 2010

\begin{tabular}{llll}
\hline Programa & Bairro/local & Tipologia & Unidades \\
\hline Tchau Aluguel & São Jorge & Apartamento & 176 \\
Tchau Aluguel & Jardim Célia & Casas & 1.136 \\
Tchau Aluguel & Jardim Europa & Casas & 10 \\
Tchau Aluguel & Campo Alegre & Casas & 39 \\
\hline Total & & & 1.361 \\
\hline
\end{tabular}

Fonte: Banco de Dados Integrado da Prefeitura Municipal de Uberlândia (UBERLÂNDIA, 2011).

Por último, foram entregues Io6 unidades habitacionais em $20 I$ (tabela 3). Destaca-se aqui um declínio considerável em relação ao ano anterior, que possivelmente se dá por conta do lançamento, em 2009, do programa habitacional de abrangência nacional Minha Casa Minha Vida, fazendo com que as iniciativas municipais se estagnassem.

Tabela 3 - Moradias construídas e entregues pelo Programa Tchau Aluguel - Uberlândia (MG), 20II

\begin{tabular}{llll}
\hline Programa & Bairro/local & Tipologia & Unidades \\
\hline Tchau Aluguel & Jardim Veneza & Casas & 18 \\
Tchau Aluguel & Distrito de Tapuirama & Casas & 51 \\
Tchau Aluguel & Maravilha & Casas & 37 \\
\hline Total & & & 106 \\
\hline
\end{tabular}

Fonte: Banco de Dados Integrado da Prefeitura Municipal de Uberlândia (UBERLÂNDIA, 2012).

O poder público municipal, ao paralisar o programa local para se utilizar do federal, não considerou que o déficit de moradia continuava em escala crescente, dado que, de acordo com o Censo Demográfico de 20I0, saltou de 5,5 milhões para 6,49 milhões de unidades habitacionais. Por outro lado, essa circunstância mostra como o programa objetivou, também, atender aos interesses dos especuladores fundiários locais com o aumento da renda da terra e do território a ser especulado, fortalecendo as elites da região e mostrando, mais

8 Observou-se que esse foi o único bairro que recebeu o conjunto habitacional em forma vertical. 
uma vez, o descompromisso em resolver de fato o problema, algo típico dos regimes de orientação social-democrata 9 .

Nesse sentido, pode-se perceber como ambos os planos, bem como as suas respectivas execuções, assemelham-se ao modelo desenvolvido pelo $\mathrm{BNH}$, já que as construções foram financiadas por um banco - entendendo-se que o capital especulativo atuou por essa via no processo - , assim como as empreiteiras que foram contratadas para realizar as obras dos conjuntos habitacionais. Esse exemplo mostra de maneira muito evidente a forma como são tratados os programas de moradia, demonstrando como esses modelos são estratégias do capital para se reproduzir, enriquecendo cada vez mais quem o detém, e oferecendo migalhas à massa proletária.

A definição da localidade onde foram construídos os conjuntos habitacionais reproduz a mesma lógica utilizada pelo $\mathrm{BNH}$, uma vez que todos são em locais distantes do centro da cidade - muitas vezes no limite legal da malha urbana — ou seja, criam-se bolsões de pobreza, isolam-se os trabalhadores e limita-se o seu acesso à cidade.

A distância da casa para o centro comercial muitas vezes cerceia o deslocamento do operário para um espaço de lazer, sendo que esse também é um direito social garantido pela Constituição Federal em seu artigo $6^{\circ}$, bem como pelo Estatuto das Cidades. Essa escolha dos locais fomenta também a especulação imobiliária, que, aliás, deveria ser combatida (mas não é) como propõe o Estatuto das Cidades e também o Sistema Nacional de Habitação de Interesse Social (SNHIS), em seus princípios:

Art. $4^{\circ}$. A estruturação, a organização e a atuação do SNHIS devem observar: I - os seguintes princípios:

a) compatibilidade e integração das políticas habitacionais federal, estadual, do Distrito Federal e municipal, bem como das demais políticas setoriais de desenvolvimento urbano, ambientais e de inclusão social;

b) moradia digna como direito e vetor de inclusão social;

c) democratização, descentralização, controle social e transparência dos procedimentos decisórios;

d) função social da propriedade urbana visando a garantir atuação direcionada a coibir a especulação imobiliária e permitir o acesso à terra urbana e ao pleno desenvolvimento das funções sociais da cidade e da propriedade (Brasil, 2005, destaques nossos).

A especulação imobiliária é um processo em que o valor do solo urbano está associado não ao seu uso, mas ao valor que pode conferir ao seu proprietário (OLIVEIRA, 1978). No modo de produção capitalista, quem regula o uso do solo é o mercado; nesse caso a "mercadoria" possui um valor de uso e o de troca (MARX, I980; SINGER, I982).

A potencialização desse processo especulativo ocorre justamente quando, em

9 A social-democracia trata o problema habitacional sob a falsa proposição de que faltam unidades habitacionais no Brasil, portanto não conseguem resolver essa situação, algo errôneo, pois na verdade não existe um real compromisso dos gestores orientados por essa matriz ideológica em apontar para o fim à propriedade privada, raiz maior do déficit de moradias. 
Estatuto das Cidades é um

instrumento inovador por

regulamentar a função social

da propriedade no espaço

urbano. Ele também traz à luz os

conflitos cotidianos que ocorrem

na cidade, fruto da lógica

organizacional da sociedade no modo de produção capitalista

vez de se utilizarem as propriedades que não estão cumprindo a sua função social na malha urbana para resolver o déficit habitacional, os chamados vazios urbanos (BRITO, 20I7), se faz opção por lotes que estão fora do perímetro urbano da cidade para alocar as moradias advindas de programas de moradia, uma opção claramente excludente.

Ao ignorar esses vazios urbanos, que poderiam ser aproveitados para construção dessas habitações, foi possível observar que tanto o Governo Federal como o municipal estão descumprindo a obrigação de zelar pela função social da propriedade, e, por consequência, de executar o Estatuto das Cidades (lei no I0.257, de Io de julho de 200I):

Art. 39. A propriedade urbana cumpre sua função social quando atende às exigências fundamentais de ordenação da cidade expressas no plano diretor, assegurando o atendimento das necessidades dos cidadãos quanto à qualidade de vida, à justiça social e ao desenvolvimento das atividades econômicas $[\ldots]$.

O Estatuto das Cidades é um instrumento inovador por regulamentar a função social da propriedade no espaço urbano. Ele também traz à luz os conflitos cotidianos que ocorrem na cidade, fruto da lógica organizacional da sociedade no modo de produção capitalista (RODRIGUES, 2004). Contudo, por vezes tem sido deixado de lado pela própria administração pública. Isso porque ele oferece mecanismos para se combater a especulação imobiliária, contrariando, mesmo que de forma parcial, os interesses do capital especulativo. Além disso, é importante frisar que os proprietários fundiários, também conhecidos como especuladores imobiliários, possuem diversos representantes nos poderes Legislativo e Executivo, e usam da "política da troca de favores”, legislando e executando em causa própria e não em benefício do proletariado.

O Estatuto das Cidades, apesar de não garantir de modo completo o direito do acesso à cidade, como demonstramos no caso específico de Uberlândia, é um instru- 
mento fundamental na luta para que esse direito seja de fato efetivado (RODRIGUES, 2004). Porém, ao analisar o PMH de Uberlândia, é possível observar que esse instrumento foi ignorado em sua execução, reproduzindo práticas que o estatuto visa coibir. Ao criar áreas urbanizadas, os "vazios" se tornam locais onde a especulação imobiliária é fomentada.

A regulação do uso do solo urbano se dá pelo mecanismo do mercado, principalmente em torno da especulação gerada pelos agentes imobiliários (SINGER, I982), e os investimentos do Estado corroboram o aumento (ou a diminuição) da renda da terra. Nesse sentido, a intervenção, mesmo conflitiva, é necessária para a contenção do mercado especulativo imobiliário.

\section{CONSIDERAÇ̃̃ES FINAIS}

Ao realizar um levantamento histórico das políticas habitacionais conduzidas pelo Estado brasileiro, com base nos marcos legais e observando os seus desdobramentos na cidade de Uberlândia, foi possível perceber que a falta de acesso da classe trabalhadora empobrecida à moradia é um problema histórico, não só daquela localidade, mas que abrange todo o território nacional.

Essa falta de acesso não tem a ver em si só com a maneira pela qual as políticas habitacionais se dão, mas com as bases estruturantes do modo de produção vigente, $o$ capitalismo. Essa organização faz com que a elite nacional - e isso também se reflete nos municípios - sempre esteja na gestão do Estado, garantindo que os seus interesses sejam prontamente atendidos.

Em Uberlândia essa realidade não é diferente: em todas as vezes em que foram construídos conjuntos habitacionais que visavam atender aos trabalhadores empobrecidos, os interesses da elite também foram atendidos, mesmo que isso se referisse ao local onde foram construídas as habitações, que sempre ficou a cargo do poder público local escolher, e em todas as experiências que observamos fica óbvio o isolamento da massa trabalhadora e o fomento da especulação imobiliária, que fez com que o valor do solo urbano subisse substancialmente.

E chegamos a algumas considerações que entendemos serem importantes nesta reflexão. Dentro do campo do ideal, diríamos que a solução é o fim do capitalismo e, por consequência, da propriedade privada, entretanto, temos clareza de que essa não é a realidade. No campo do possível, da nossa realidade concreta, também é possível pensar em outro modelo de política habitacional, que, além de levar em consideração as necessidades da população de ter acesso a uma habitação digna, considere, de forma real, a função social dos imóveis em situação de vacância e os instrumentos legalmente constituídos, como o Estatuto das Cidades.

Entendemos que essas práticas podem mudar a realidade de Uberlândia, uma cidade construída em retalhos para favorecer a especulação imobiliária. Os marcos legais, como o Estatuto das Cidades, foram ignorados pelo poder público, e isso interfere 
cotidianamente na realidade dos trabalhadores e trabalhadoras que passam muitas horas do seu dia se deslocando entre o lar — em locais distantes da região central da cidade, que é onde conseguem pagar um aluguel, ou mesmo por terem sido contemplados com o acesso facilitado ao domicílio por uma política habitacional - e o local de trabalho, o que precariza ainda mais a rotina desses trabalhadores. E é por considerar a condição dos milhares de trabalhadores e trabalhadoras que se encontram nessa situação que devemos pensar uma política de habitação que rompa com esses estereótipos e sirva de fato a essa parte da população.

Nessa perspectiva, é necessário ressaltar que, para que isso ocorra, devemos atravessar uma profunda transformação social e política visando à implantação de um novo projeto nacional de desenvolvimento, que tenha como pilar a solução dos problemas enfrentados pela população brasileira, entre eles o déficit de acesso à habitação.

* Graduada em Geografia pela Universidade Federal de Uberlândia (UFU), mestre em Geografia pela Universidade Federal de Goiás - Regional Catalão (UFG-RC) e doutoranda em Geografia pela Universidade Federal de Uberlândia (UFU). E-mail: raphaella.udi@gmail.com

** Graduado em Geografia e Ciências Biológicas, mestre em Sustentabilidade e doutor em Ciências Naturais pela Universidade Federal de Ouro Preto (Ufop). Docente do Instituto Federal de Minas Gerais - campus avançado Piumhi. E-mail: pedro0peixe@yahoo.com.br

*** Graduada e mestre em Geografia pela UFG e doutora em Geografia pela Universidade de São Paulo (USP). Docente da Universidade Federal de Catalão (Ufcat).E-mail: clcgeo@gmail.com

Texto recebido em novembro de 2020; aprovado em fevereiro de 2021 
ARIMATEIA, Emmanuela Wanderly Campos. O descompasso de uma experiência: avaliação do Programa Habitar Brasil na Comunidade África - Natal-RN. 2006. 162 f. Dissertação (Mestrado em Arquitetura e Urbanismo) - Centro de Tecnologia, Departamento de Arquitetura, Universidade Federal do Rio Grande do Norte, Natal, 2006.

ARRETCHE, Marta. Federalismo e relações intergovernamentais no Brasil: a reforma dos programas sociais. Dados, v. 45, n. 3, p. 431-457, 2002.

AZEVEDO, Sergio. Vinte e dois anos de política de habitação popular (1964-86): criação, trajetória e extinção do BNH. Revista de Administração Pública, v. 22, n. 4, p. 107-199, 1988.

BENCHIMOL, Jaime Larry. Pereira Passos: um Haussmann tropical — a renovação urbana da cidade do Rio de Janeiro no início do século XX. Rio de Janeiro: Secretaria Municipal de Cultura, Turismo e Esportes, 1992.

BIHR, Alain. Da grande noite à alternativa: o movimento operário europeu em crise. São Paulo: Boitempo, 2010.

BOLAFFI, Gabriel. Habitação e urbanismo: o problema e o falso problema. In: MARICATO, Ermínia (Org.). A produção capitalista da casa (e da cidade) no Brasil industrial. 2 ed. São Paulo: Alfa-Omega, 1982. p. 37-70.

BONATES, Mariana Fialho. O Programa de Arrendamento Residencial — PAR: acesso diferenciado à moradia e à cidade. Risco, São Carlos, v. 7, p. 147-164, 2008.

BONDUKI, Nabil. Política habitacional e inclusão social no Brasil: revisão histórica e novas perspectivas no governo Lula. Revista Eletrônica de Arquitetura e Urbanismo, São Paulo, n. 1, p. 70-104, 2008. Disponível em: < https://revistaarqurb.com.br/arqurb/article/view/81/75>. Acesso em: 18 nov. 2018.

BOTEGA, Leonardo da Rocha. De Vargas a Collor: urbanização e política habitacional no Brasil. Espaço Plural, n. 17, p. 66-72, 2007.

BRASIL. Constituição da República Federativa do Brasil de 1988. Brasília: Presidência da República, 1988. Disponível em: <www.planalto.gov.br/ccivil_03/constituicao/constituicao.htm>. Acesso em: 10 fev. 2021.

Lei $n^{\circ}$ 10.257, de 10 de julho de 2001. Estatuto da Cidade e legislação correlata. 2. ed. Brasília: Senado Federal, 2002.

Lei $\mathbf{n}^{\circ}$ 11.124, de 16 de Junho de 2005. Dispõe sobre o Sistema Nacional de Habitação de Interesse Social — SNHIS, cria o Fundo Nacional de Habitação de Interesse Social — FNHIS e institui o Conselho Gestor do FNHIS. Brasília: Presidência da República, 2005. Disponível em: <www.planalto. gov.br/ccivil_03/_ato2004-2006/2005/lei/l11124.htm>. Acesso em: 10 fev. 2021. 2004.

Política nacional de habitação. Cadernos MCidades, n. 4. Brasília: Ministério das Cidades,

BRITO, Paula Santos. Função social da propriedade, vazios urbanos e desdobramentos na política de habitação de interesse social no município de Feira de Santana. 2017. 111 f. Dissertação (Mestrado em Planejamento Territorial) - Departamento de Ciências Humanas e Filosofia, Universidade Estadual de Feira de Santana, Feira de Santana, 2017.

CAMARGO, Pedro Luiz Teixeira. Valor ambiental da cachoeira da Serrinha, Mariana-MG. Curitiba: Appris, 2018.

CAMPOS, Pedro Henrique Pedreira. Empresariado e ditadura no Brasil: o estado atual da questão e o caso dos empreiteiros de obras públicas. Transversos, n. 12, p. 335-358, 2018.

CARLOS, Ana Fani Alessandri. O espaço urbano: novos escritos sobre a cidade. 1. ed. São Paulo: Contexto, 2004.

CARVALHO, Inaiá Maria Moreira. Capital imobiliário e desenvolvimento urbano. Caderno CRH, v. 26, n. 69, p.545-562, 2013. 
COELHO, André. Mais casa sem gente do que gente sem casa. 2018. Disponível:< https://www2. senado.leg.br/bdsf/bitstream/handle/id/513614/noticia.html?sequence=1 > . Acesso em: 8 fev. 2019.

COLIGAÇÃO LULA PRESIDENTE. Programa de governo 2002. Disponível em: <www1.uol.com.br/ fernandorodrigues/arquivos/eleicoes02/plano2002-lula.pdf>. Acesso em: 10 fev. 2021.

CORREAA, Roberto Lobato. O espaço urbano. São Paulo: Ática, 2004.

DEO, Anderson. A consolidação da social-democracia no Brasil. 303 f. 2011. Tese (Doutorado em Ciências Sociais) — Faculdade de Filosofia e Ciências, Universidade Estadual Paulista, Marília, 2011.

FERREIRA, Andressa Rosa. Programas de combate ao déficit habitacional brasileiro. 72 f. 2009. Trabalho de Conclusão de Curso (Graduação em Ciências Econômicas) — Departamento de Ciências Econômicas, Universidade Federal do Rio Grande do Sul, Porto Alegre, 2009.

GOMES, Maria Fátima Cabral Marques. Habitação e questão social: análise do caso brasileiro. Scripta Nova, v. 4, n. 194,p.1-2, ago. 2005.

HARVEY, David. O direito à cidade. Lutas Sociais, São Paulo, n. 29, p. 73-89, jul.-dez. 2012.

IBGE. Censo 2010. Disponível em: <https://censo2010.ibge.gov.br/resultados.html>. Acesso em: 10 fev. 2021.

ISIDORO, Marcos Paulo. A dinâmica comercial no bairro Luizote de Freitas: avenida José Fonseca e Silva. 2006. 43 f. Trabalho de Conclusão de Curso (Graduação em Geografia) — Instituto de Geografia, Universidade Federal de Uberlândia, Uberlândia, 2006.

KOWARICK, Lúcio. A espoliação urbana. Rio de Janeiro: Paz e Terra, 1979.

LEFEBVRE, Henri. O direito à cidade. São Paulo: Centauro, 2001.

LORENZETTI, Maria Sílvia Barros. A questão habitacional no Brasil. Brasília: Câmara dos Deputados, 2001.

LUXEMBURGO, Rosa. Reforma ou revolução?. São Paulo: Expressão Popular, 2003.

MACÊDO, Paulo César. Jardim Célia: sonho dourado ou martírio? Segregação e exílio social "que nasceu no meio do cerrado" — Uberlândia, 2009-2014. 2014. 112 f. Dissertação (Mestrado em História) — Instituto de História, Universidade Federal de Uberlândia, Uberlândia, 2014.

MACIEL, Ana Paula; BALTAZAR, Ana Paula. Família sem casa e casas sem família: o caso da Região Metropolitana de Belo Horizonte. Cadernos Metrópole, v. 13, n. 26, p. 523-547, 2011.

MARICATO, Ermínia. Política urbana e de habitação social: um assunto pouco importante para o governo FHC. Revista Praga, v. 1, n. 6, p. 67-78, 1998.

O impasse da política urbana no Brasil. Petrópolis: Vozes, 2011.

MARX, Karl. O Capital: crítica da economia política. 30. ed. São Paulo: Civilização Brasileira, 1980. 574p. [Livro 1]

O 18 de brumário de Luís Bonaparte. 1.ed.São Paulo: Boitempo, 2011. 176p.

O Capital: crítica da economia política. 2. ed. São Paulo: Boitempo, 2013. 894p. [Livro 1]

MEDEIROS, Sara Raquel Fernandes Queiroz. BNH: outras perspectivas. In: CONFERÊNCIA NACIONAL DE POLÍTICAS PÚBLICAS CONTRA A POBREZA E A DESIGUALDADE, 1., 2010, Natal. Anais [...]. Natal: UFRN, 2010. p. 1-15.

MONTEIRO, Adriana Roseno; VERAS, Antônio Tolrino de Rezende. A questão habitacional no Brasil. Mercator, Fortaleza, v. 16, p.1-12 2017.

MORAES, Reginaldo. Neoliberalismo: de onde vem, para onde vai?. São Paulo: Editora Senac, 2001. MOREIRA, Camila Fernandes; LEME, Alessandro André. Direito à moradia: políticas públicas nos governos FHC e Lula. Horizonte Científico, Uberlândia, v. 5, p. 1-22, 2011. 
MOURA, Gerusa Gonçalves; SOARES, Beatriz Ribeiro. A periferia de Uberlândia: da sua origem até a sua expansão nos anos 1990. Caminhos de Geografia, v. 10, p. 22-40, 2009.

NOAL, Ednilson Bolson; JANCZURA, Rosane. A política nacional de habitação e a oferta de moradias.

Textos \& Contextos, Porto Alegre, v. 10, n. 1, p. 157-169, jan.-jul. 2011.

OLIVEIRA, Ariovaldo Umbelino de. A lógica da especulação imobiliária. Boletim Paulista de Geografia, n. 55, p.75-92,1978.

PRZEWORSKI, Adam. A social-democracia como fenômeno histórico. Lua Nova, Revista de Cultura e Política, v. 4, n. 15, p. 41-81, 1988.

RIBEIRO, Edaléa Maria. A política de habitação no Brasil em tempos de globalização neoliberal. In: JORNADA INTERNACIONAL DE POLÍTICAS PÚBLICAS, 3., 2007, São Luís. Anais [...]. São Luís: UFMA, 2007.

RODRIGUES, Arlete Moysés. Estatuto da Cidade: função social da cidade e da propriedade. Alguns aspectos sobre população urbana e espaço. Cadernos Metrópole, n. 12, p. 9-25, 2004.

SINGER, Paul. O uso do solo urbano na economia capitalista. In: MARICATO, Ermínia (Org.). A produção capitalista da casa (e da cidade) no Brasil industrial. São Paulo: Alfa-Omega, 1982. p. 21-36.

SOARES, Beatriz Ribeiro. Habitação e produção do espaço em Uberlândia. 1988. 225 f. Dissertação (Mestrado em Geografia) — Faculdade de Filosofia, Letras e Ciências Humanas, Universidade de São Paulo, São Paulo, 1988.

SOUSA, Milena Abadia de. A ONG Ação Moradia e a zona leste do município de Uberlândia-MG: os impactos do terceiro setor na periferia. 2016. 182 f. Dissertação (Mestrado em Educação) — Faculdade de Educação, Universidade Federal de Uberlândia, Uberlândia, 2016.

SOUZA, Amanda Paulista de. As mulheres nos movimentos sociais de moradia: a cidade sob uma perspectiva de gênero. Revista Humanidades em Diálogo, v. 5, p. 93-108, 2013.

SOUZA, Bárbara Cecília Machado Fontes de. Desenvolvimento regional e gestão metropolitana: reflexões a partir da política habitacional na região metropolitana de Aracaju. 2009. 140 f. Dissertação (Mestrado em Desenvolvimento Regional e Gestão de Empreendimentos Locais) — Núcleo de Pós-Graduação e Pesquisa em Economia, Universidade Federal de Sergipe, São Cristóvão, 2009.

SOUZA, Lilian Aparecida. Considerações acerca da mercadoria moradia: a questão habitacional. Espaço em Revista, v.18, n.2, p.67-84, 2016.

TOURINHO, Adriana de Oliveira. A influência das reformas urbanas parisienses no Rio de Janeiro dos anos 20. In: JORNADAS DO PROGRAMA DE PÓS-GRADUAÇÃO EM HISTÓRIA SOCIAL DA UFRJ, $1 .$, 2007. Anais [...]. Rio de Janeiro: Universidade Federal do Rio de Janeiro, 2007.

UBERLÂNDIA. Lei $\mathbf{n}^{\circ} \mathbf{9 . 0 8 0}$, de 25 de outubro de 2005. Dispõe sobre o Plano Municipal de Habitação "Tchau Aluguel" e dá outras providências. Disponível em: <https://leismunicipais.com.br/a/ mg/u/uberlandia/lei-ordinaria/2005/908/9080/lei-ordinaria-n-9080-2005-dispoe-sobre-o-plano-municipal-de-habitacao-tchau-aluguel-e-da-outras-providencias>. Acesso em: 10 fev. 2021.

UBERLÂNDIA. Banco de Dados Integrados - Ano base 2008. Uberlândia: Secretária de Planejamento Urbano, 2009. 397p.

UBERLÂNDIA. Banco de Dados Integrados - Ano base 2010. Uberlândia: Secretária de Planejamento Urbano, 2011. 385p.

UBERLÂNDIA. Banco de Dados Integrados - Ano base 2011. Uberlândia: Secretária de Planejamento Urbano, 2012. 402p.

VALENÇA, Márcio Moraes. Habitação: notas sobre a natureza de uma mercadoria peculiar. Cadernos Metrópole, n. 9, p. 165-171, 2003. 